\title{
A Canadian clinical practice algorithm for the management of patients with nonvariceal upper gastrointestinal bleeding
}

\author{
Alan Barkun MD CM MSc ${ }^{1}$, Carlo A Fallone MD¹, Naoki Chiba MD MSc ${ }^{2}$, Marty Fishman ${ }^{3}$, Nigel Flook MD CCFP FCFP ${ }^{4}$, \\ Janet Martin BScPhm PharmD ${ }^{5}$, Alaa Rostom MD MSc FRCPC ${ }^{6}$, Anthony Taylor MD ${ }^{7}$, \\ for the Nonvariceal Upper GI Bleeding Consensus Conference Group*
}

\begin{abstract}
A Barkun, CA Fallone, N Chiba, et al. A Canadian clinical practice algorithm for the management of patients with nonvariceal upper gastrointestinal bleeding. Can J Gastroenterol 2004;18(10):605-609.
\end{abstract}

AIM: To use current evidence-based recommendations to provide a user-friendly clinical algorithm for the management of upper gastrointestinal bleeding, adapted to the Canadian environment.

METHODS: A multidisciplinary consensus group of 25 participants representing 11 national societies used a seven-step approach to develop recommendations according to accepted standards. Sources of data included narrative and systematic reviews as well as published and new meta-analyses. A small writing subgroup subsequently created the algorithm.

RESULTS: Recommendations emphasize appropriate initial resuscitation of the patient and a multidisciplinary approach to clinical risk stratification that determines the need for early endoscopy. Early endoscopy allows safe and prompt discharge of selected patients classified as low risk. Endoscopic hemostasis is reserved for patients with high-risk endoscopic lesions. Although monotherapy with injection or thermal coagulation is effective, the combination is superior to either treatment alone. High-dose intravenous proton-pump inhibition is recommended in patients who have undergone successful endoscopic therapy. Routine second-look endoscopy is not recommended. Patients with upper gastrointestinal bleeding secondary to ulcer disease should be tested and treated for Helicobacter pylori infection.

CONCLUSIONS: This algorithm should facilitate appropriate risk stratification, use of endoscopic therapy and the appropriate utilization of proton-pump inhibition to optimize the care of patients with upper gastrointestinal bleeding. The algorithm should be customized to the resources of individual medical centres. Its application should be studied with appropriate outcomes recorded and validation performed.

Key Words: Algorithm; Bleeding; Gastrointestinal; Nonvariceal
Un algorithme de pratique clinique canadien pour la prise en charge de patients souffrant de saignements non variqueux des voies gastro-intestinales supérieures

\begin{abstract}
OBJECTIF : Utiliser les recommandations courantes fondées sur des faits probants pour fournir un algorithme facile à utiliser et adapté au milieu canadien dans la prise en charge des saignements des voies gastrointestinales supérieures.

MÉTHODOLOGIE : Un groupe multidisciplinaire consensuel de 25 participants représentant 11 sociétés nationales a recouru à une démarche en sept étapes pour élaborer des recommandations fondées sur des normes acceptées. Les sources de données incluaient des analyses narratives et systématiques et des méta-analyses publiées ou nouvelles. Un petit sousgroupe de rédaction a ensuite créé l'algorithme.

RÉSULTATS : Les recommandations font ressortir l'importance d'une réanimation initiale convenable des patients et d'une approche multidisciplinaire de la stratification des risques cliniques qui détermine le besoin d'une endoscopie précoce. Cette endoscopie permet d'accorder un congé hospitalier sécuritaire et rapide à des patients sélectionnés classés comme à faible risque. L'hémostase endoscopique est réservée aux patients présentant des lésions endoscopiques à haut risque. Bien qu'une monothérapie par injection ou une coagulation thermique soit efficace, l'association est supérieure à l'un ou l'autre des traitements employé seul. De fortes doses d'inhibiteurs de la pompe à protons par voie intraveineuse sont recommandées pour les patients qui ont subi un traitement endoscopique réussi. Les patients souffrant de saignements des voies gastro-intestinales supérieures secondaires à une maladie ulcéreuse devraient subir des examens et un traitement contre l'infection à l'Helicobacter pylori.

CONCLUSIONS : Cet algorithme devrait faciliter une stratification pertinente des risques, l'usage du traitement endoscopique et l'utilisation pertinente des inhibiteurs de la pompe à protons pour optimiser les soins des patients souffrant de saignements de voies gastro-intestinales supérieures. L'algorithme devrait être personnalisé selon les ressources de chaque centre médical. Son application devrait être évaluée, les issues
\end{abstract} devraient être prises en note et une validation devrait être exécutée.

${ }^{1}$ Department of Medicine, Division of Gastroenterology, McGill University, Montreal, Quebec; ${ }^{2}$ Division of Gastroenterology, McMaster University, Hamilton, Ontario; ${ }^{3}$ Division of Gastroenterology, University of British Columbia, Vancouver, British Columbia; ${ }^{4}$ Department of Family Medicine, University of Alberta, Edmonton, Alberta; ${ }^{5}$ Department of Physiology $\mathcal{E}$ Pharmacology, University of Western Ontario, London, Ontario; ${ }^{6}$ Division of Gastroenterology, University of Ottawa, Ottawa, Ontario; 7 Department of Emergency Medicine, Calgary Health Region, University of Calgary, Calgary, Alberta; *See Appendix 1

Correspondence: Dr Alan Barkun, Division of Gastroenterology, Montreal General Hospital Site, The McGill University Health Centre, 1650 Cedar Avenue, Room D7.148, Montreal, Quebec H3G 1A4. Telephone 514-934-8233, fax 514-934-8375,

e-mail alan.barkun@muhc.mcgill.ca

Received for publication March 15, 2004. Accepted July 13, 2004 


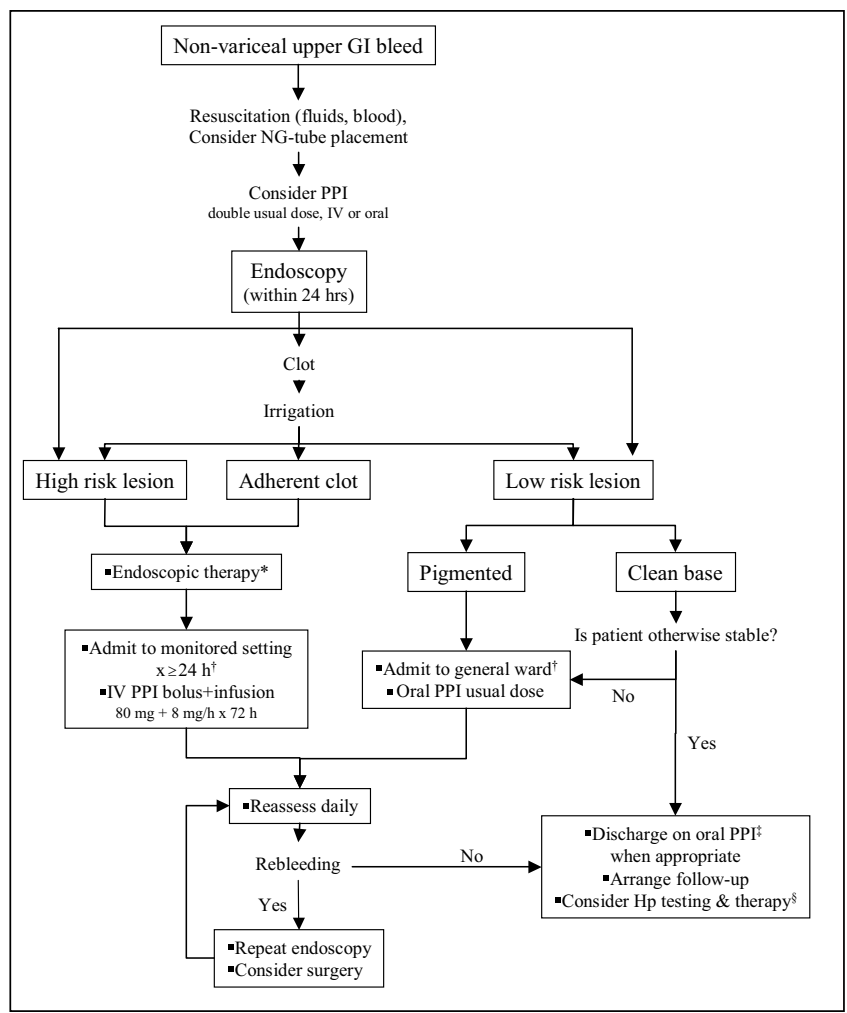

Figure 1) A Canadian clinical practice algorithm for the management of patients with nonvariceal upper gastrointestinal (GI) bleeding. Refer to the text for relevant references. *Combination therapy with injection plus thermocoagulation is preferred; ${ }^{\dagger}$ High-risk patients can be moved to a general ward after $24 \mathrm{~h}$ if appropriate. The duration of admission should take into consideration the rebleeding period $(72 \mathrm{~h})$, local practice and availability of resources; $\$$ There are no data favouring protonpump inhibitors (PPIs) over histamine $2_{2}$-receptor antagonists as oral follow-up therapy, but this is a reasonable approach, because this was the strategy in the high-dose intravenous (IV) PPI studies; ${ }^{\S}$ Acute testing for Helicobacter pylori $(\mathrm{H} p)$ should be followed, if negative, by a confirmatory test once bleeding has resolved. There is no rationale for urgent IV eradication therapy; oral therapy can be initiated either immediately or during follow-up of patients who are $\mathrm{H}$ pylori-positive. Early discharge is appropriate in the absence of risk factors such as age over 65 years, shock, comorbid illnesses and fresh red blood on rectal examination, in the emesis or in the nasogastric (NG) aspirate

$\mathrm{U}$ pper gastrointestinal (GI) bleeding represents a substantial clinical and economic burden, with a prevalence of approximately 170 cases per 100,000 adults per year (1). Approximately $50 \%$ to $70 \%$ of cases are due to peptic ulcer disease $(2,3)$, and despite recent advances in therapy, an estimated $6 \%$ to $8 \%$ of these patients die $(1,4,5)$. Causes can broadly be divided into variceal and nonvariceal with limited accurate prediction based on clinical criteria alone.

With the exception of the recent British Society of Gastroenterology guidelines (2002) (6), the last widely disseminated consensus conference and publication of practice guidelines occurred more than 10 years ago $(7,8)$. For this reason, a multidisciplinary consensus conference was held in Canada in June 2002. The group included Canadian and international gastroenterologists, endoscopists, surgeons, family physicians, emergency room physicians, pharmacologists, epidemiologists (with methodological and health economic expertise) and a hospital pharmacist, representing 11 national societies. Using stringent, accepted criteria for guideline development, new data and a series of evidence-based systematic reviews and meta-analyses $(9,10)$, recommendations for the management of nonvariceal upper GI bleeding were developed (11). The complete review and consensus processes details are published in full elsewhere (11). These consensus recommendations have now been used to develop an algorithm for the management of patients with nonvariceal upper GI bleeding specifically tailored to the Canadian environment.

\section{RECOMMENDATIONS}

The present article will present highlights of the recommendations (published in full in the Annals of Internal Medicine 2003 [11]) as they relate, in a Canadian setting, to decision points in the algorithm shown in Figure 1.

\section{Stabilization}

When a patient presents with a nonvariceal upper GI bleed, appropriate initial resuscitation, including stabilization of blood pressure and restoration of intravascular volume, is paramount and should precede any further diagnostic and therapeutic measures (11). Placement of a nasogastric tube should be considered in selected patients because the findings may have prognostic value $(11,12)$. Empiric therapy with a high dose, oral or intravenous, proton-pump inhibitor (PPI) should be considered for patients awaiting endoscopy (11), but is not a replacement for urgent endoscopy and hemostasis, where appropriate $(3,13-16)$. Although there are no controlled data directly assessing this approach, its possible usefulness is suggested by the conclusions of randomized trials of postendoscopy high dose oral (13-16) and intravenous PPI $(17-20)$, coupled with results from preliminary observational and cost-effectiveness studies $(3,21,22)$.

\section{Clinical risk stratification}

Approximately $80 \%$ of patients will stop bleeding spontaneously without recurrence, but the main goal of management is to identify the remaining $20 \%$ of patients who are at greatest risk of morbidity and mortality from continued or recurrent bleeding (23).

Once patients are clinically stabilized, they should be stratified into low- and high-risk categories for rebleeding and mortality, based on clinical criteria initially, with endoscopic criteria also considered when available (11). The most important clinical predictors of increased risk of rebleeding or mortality are age over 65 years, shock, comorbid illnesses and fresh red blood on rectal examination, in the emesis or in the nasogastric aspirate $(3,11,24-30)$. Endoscopic stigmata defined as low- and high-risk are discussed below.

The need for urgent endoscopy, or conversely, suitability for early discharge, can be determined using risk stratification tools, such as those reported by Blatchford et al (31) or Cameron et al (32), which include older age, significant comorbid illnesses, presence of hematemesis, shock or syncope.

\section{Endoscopic risk stratification and therapy}

Endoscopy should be performed within the first $24 \mathrm{~h}$, the patient stratified according to the endoscopic stigmata and endoscopic therapy performed if needed. Clinical risk stratification 
according to the criteria mentioned above, can assist in differentiating between those who require urgent endoscopy (based on clinical criteria) and those who can safely wait for a finite period of time, depending on available resources. Evidence indicates that the risk of further bleeding is strongly associated with the hemorrhagic stigmata seen at endoscopy. The risk is reportedly less than $5 \%$ in patients with a clean ulcer base, and increases progressively with a flat spot $(10 \%)$, adherent clot $(22 \%)$, nonbleeding visible vessel $(43 \%)$ or active bleeding (oozing and spurting, 55\%) (11,23).

Recently it has been demonstrated in randomized controlled trials that a single dose of intravenous erythromycin (3 $\mathrm{mg} / \mathrm{kg}$ infusion over $30 \mathrm{~min}$ or $250 \mathrm{mg}$ bolus) administered $20 \mathrm{~min}$ to $90 \mathrm{~min}$ before endoscopy improves the visibility and quality of the examination, and decreases the need for repeat examinations $(33,34)$. Erythromycin acts as a potent gastrokinetic to empty the stomach of blood; a clear stomach was found significantly more often with erythromycin than with placebo (82\% versus 33\%) (34). Erythromycin may be useful in patients undergoing emergency endoscopy for upper GI bleeding when blood obscures visibility.

A finding of active bleeding or a visible vessel in an ulcer bed (high-risk lesion) requires immediate endoscopic hemostatic therapy, while a finding of a clean-based ulcer or a nonprotuberant pigmented dot (low-risk lesion) does not $(11,23)$. The optimal management of adherent clots remains more controversial (11). Adherent clots obscure underlying stigmata that may be at high or low risk of rebleeding. Recent evidence supports that a clot in an ulcer bed should undergo targeted irrigation in an attempt to dislodge it and the underlying lesion treated appropriately $(35,36)$.

High-risk lesions should be treated with endoscopic therapy. Monotherapy, with injection or thermal coagulation $(9,10)$, is an effective endoscopic hemostatic technique for high-risk stigmata, but the combination is superior to either treatment alone (11,35-37).

Clinical and endoscopic classification of risk allows for safe and prompt discharge of patients classified as low-risk; improves patient outcomes for patients classified as high-risk; and reduces resource utilization for patients in all classifications (11,38-44). Clinical criteria for early discharge generally include age less than 60 years, stable vital signs, no endoscopic stigmata or flat spot, and no concomitant serious medical illness $(39,45)$.

\section{Acid suppressive therapy}

Recent meta-analyses have found PPIs to be more effective than histamine ${ }_{2}$-receptor antagonists $\left(\mathrm{H}_{2}-\mathrm{RAs}\right)$ in preventing persistent or recurrent bleeding $(9,10,46,47) . \mathrm{H}_{2}$ - $\mathrm{RAs}$ have demonstrated inconsistent and only marginal benefits, and, as such, are not recommended for the management of acute upper GI bleeding (11). High-dose PPI therapy administered by intravenous bolus followed by continuous infusion is effective in decreasing rebleeding in patients who have undergone successful endoscopic therapy and should be used to treat patients with high-risk endoscopic stigmata, including adherent clots (9-11). Evidence suggests a class effect for PPI treatment and that improvement in rebleeding rates can be achieved using either intravenous omeprazole or pantoprazole at a dose of $80 \mathrm{mg}$ bolus followed by $8 \mathrm{mg} / \mathrm{h}$ for the $72 \mathrm{~h}$ following endoscopic therapy (11). Patients can be safely switched to oral PPI therapy following the $72 \mathrm{~h}$, or when oral intake has been reestablished in those at lower risk. As mentioned above in the section on stabilization, empiric therapy with an oral PPI can be considered for patients awaiting endoscopy, particularly in institutions where intravenous PPI or endoscopy is not available (11).

\section{Admission and follow-up}

Patients identified as being at high risk of rebleeding, such as those with active bleeding or visible vessels, and those with adherent clots, should be admitted to a monitored setting for at least the first $24 \mathrm{~h}$ and receive high-dose PPI therapy $(6,11)$. If intensive care beds are unavailable, wards with more intensive monitoring than standard units can be considered. The greatest risk of rebleeding is in the first $72 \mathrm{~h}$ after endoscopy. Routine second-look endoscopy is not recommended $(11,48)$; a second look is indicated in cases of rebleeding, and perhaps in selected patients at high risk of rebleeding $(11,49)$. Patients who have failed endoscopic therapy or who are at high risk of failing endoscopic therapy should receive a surgical consultation (11), or alternatively, angiography with possible embolization could be considered (50).

Patients with a low-risk lesion who are not yet stable or those with pigmented lesions should be admitted for at least the first $24 \mathrm{~h}$ and treated with an oral PPI (11). Those with endoscopic findings of a Mallory-Weiss tear or an ulcer with a clean base or flat spot, who are otherwise stable, may be discharged home on an oral PPI (11). Studies show that patients with these endoscopic findings are at low risk and no major complications have been reported in those triaged to outpatient care (38-41,51-54).

All hospitalized patients, high or low risk, should be monitored and assessed daily, and when stable, discharged with appropriate follow-up arranged (11). If not performed during the hospitalization, Helicobacter pylori testing should be done as part of follow-up in patients with peptic ulcers (11). Eradication of $H$ pylori can reduce the rate of ulcer recurrence and rebleeding (55-58). Negative tests in the setting of acute bleeding or after initiation of PPI therapy should be interpreted with caution $(11,59)$.

This treatment approach also applies to patients with nonsteroidal anti-inflammatory drug-associated ulcers; however, the roles of cyclooxygenase-2 selective inhibitors, and coprescription with a PPI or misoprostol, were beyond the scope of the published recommendations (11).

\section{SUMMARY}

It is hoped that this algorithm will be used to direct clinical and endoscopic risk stratification, the application of endoscopic therapy and the appropriate use of PPIs, and thus help optimize the care of patients with upper GI bleeding. The algorithm should be customized to the resources of individual medical centres. The impact of the recommendations should be studied with appropriate outcomes recorded and validation performed. The efficacy of newer endoscopic therapeutic technologies, the optimal regimen of PPIs and the roles of other pharmacological agents all require further research and as such, it is anticipated that the guidelines and this algorithm will need to be updated as new data become available. 


\section{APPENDIX 1: LIST OF ATTENDEES *Nonvariceal Upper GI Bleeding Consensus Conference Group}

Canadian participants: John K Marshall (nonvoting chair), David Armstrong, Marc Bardou, Alan Barkun, J Decker Butzner, Naoki Chiba, Alan Cockeram, Brian Craig, Robert Enns, Carlo A Fallone, Marty Fishman, Nigel Flook, Jamie Gregor, Jonathan Love, Norm Marcon, Janet Martin, Joseph Romagnuolo, Alaa Rostom, Sandrine Sabbah, Anthony Taylor, Alan Thomson, Sander Veldhuyzen van Zanten, Robin McLeod (reviewed manuscript only).

International participants: Livio Cipolletta, Martin Freeman, James Lau, Joseph Sung.

ACKNOWLEDGEMENTS: The authors wish to thank Pauline Lavigne for the preparation of the manuscript.

ENDORSEMENT: The consensus conference was endorsed and organized by the Canadian Association of Gastroenterology and was held in Banff, Alberta, from June 8 to 9, 2002.

FINANCIAL SUPPORT: This work was supported, in part, by "arms length" grants to the Canadian Association of Gastroenterology from Abbott Laboratories Ltd, Altana Pharma Canada Inc, AstraZeneca Canada, Carsen Group Inc (distributors for Olympus in Canada), Janssen-Ortho Inc, Pentax Precision Instrument Corp, a peer-reviewed grant from the Canadian Institutes for Health Research and an institutional award from the McGill University Health Centre Research Institute.

\section{REFERENCES}

1. Blatchford O, Davidson LA, Murray W, Blatchford M, Pell J. Acute upper gastrointestinal haemorrhage in west of Scotland: Case ascertainment study. BMJ 1997;315:510-4.

2. Marshall JK, Collins SM, Gafni A. Prediction of resource utilization and case cost for acute non-variceal upper gastrointestinal hemorrhage at a Canadian community hospital. Am J Gastroenterol 1999;94:1841-6.

3. Barkun AN, Chiba N, Enns R, et al. Use of a national endoscopic database to determine the adoption of emerging pharmacological and endoscopic technologies in the everyday care of patients with upper GI bleeding: The RUGBE initiative. Am J Gastroenterol 2001;96:S261. (Abst)

4. Jiranek GC, Kozarek RA. A cost-effective approach to the patient with peptic ulcer bleeding. Surg Clin North Am 1996;76:83-103.

5. Silverstein FE, Gilbert DA, Tedesco FJ, Buenger NK, Persing J. The national ASGE survey on upper gastrointestinal bleeding. II. Clinical prognostic factors. Gastrointest Endosc 1981;27:80-93.

6. British Society of Gastroenterology Endoscopy Committee. Non-variceal upper gastrointestinal haemorrhage: Guidelines. Gut 2002;51(Suppl IV):iv1-6.

7. Therapeutic endoscopy and bleeding ulcers. Natl Inst Health Consens Dev Conf Consens Statement 1989;7:1-7.

8. Guidelines for good practice in and audit of the management of upper gastrointestinal haemorrhage. Report of a joint working group of the British Society of Gastroenterology, the Research Unit of the Royal College of Physicians of London and the Audit Unit of the Royal College of Surgeons of England. J R Coll Physicians Lond 1992;26:281-9.

9. Bardou M, Youssef M, Toubouti Y, Benhaberou-Brun D, Rahme E, Barkun A. Newer endoscopic therapies decrease both rebleeding and mortality in high risk patients with acute peptic ulcer bleeding: A series of meta-analyses. Gastroenterology 2003;123:A239. (Abst)

10. Bardou M, Toubouti Y, Benhaberou-Brun D, Rahme E, Barkun A. High dose proton pump inhibition decreases both re-bleeding and mortality in high-risk patients with acute peptic ulcer bleeding. A series of meta-analyses. Gastroenterology 2003;123:A625. (Abst)
11. Barkun A, Bardou M, Marshall JK, Non-variceal Upper GI Bleeding Consensus Conference Group. Consensus recommendations for managing patients with nonvariceal upper gastrointestinal bleeding. Ann Intern Med 2003;139:843-57.

12. Aljebreen A, Fallone C, Barkun A. Nasogastric aspirate predicts high-risk endoscopic lesions in patients with acute upper-GI bleeding. Gastrointest Endosc 2004;59:172-8.

13. Khuroo MS, Yattoo GN, Javid G, et al. A comparison of omeprazole and placebo for bleeding peptic ulcer. N Engl J Med 1997;336:1054-8.

14. Jung H, Son H, Jung S, et al. Comparison of oral omeprazole and endoscopic ethanol injection therapy for prevention of recurrent bleeding from peptic ulcers with nonbleeding visible vessels or fresh adherent clots. Am J Gastroenterol 2002;97:1736-40.

15. Javid G, Masoodi I, Zargar SA, et al. Omeprazole as adjuvant therapy to endoscopic combination injection sclerotherapy for treating bleeding peptic ulcer. Am J Med 2001;111:280-4.

16. Kaviani M, Hashemi M, Kazemifar A, et al. Effect of oral omeprazole in reducing re-bleeding in bleeding peptic ulcers: A prospective, double-blind, randomized, clinical trial. Aliment Pharmacol Ther 2003;17:211-6.

17. Goletti O, Sidoti F, Lippolis PV, De Negri F, Cavina E. Omeprazole versus ranitidine plus somatostatin in the treatment of severe gastroduodenal bleeding: A prospective, randomized, controlled trial. Ital J Gastroenterol 1994;26:72-4.

18. Hasselgren G, Lind T, Lundell L, et al. Continuous intravenous infusion of omeprazole in elderly patients with peptic ulcer bleeding. Results of a placebo-controlled multicenter study. Scand J Gastroenterol 1997;32:328-33.

19. Lau J, Sung J, Lee K, et al. Effect of intravenous omeprazole on recurrent bleeding after endoscopic treatment of bleeding peptic ulcers. N Engl J Med 2000;343:310-6.

20. Lin HJ, Lo WC, Lee FY, Perng CL, Tseng GY. A prospective randomized comparative trial showing that omeprazole prevents rebleeding in patients with bleeding peptic ulcer after successful endoscopic therapy. Arch Intern Med 1998;158:54-8.

21. Barkun A, Kennedy W, Herba K, Fallone C, and RUGBE Investigators. The cost effectiveness of proton pump inhibitor continuous infusion (IV PPI) administered prior to endoscopy in the treatment of patients with non-variceal upper GI bleeding. Gastroenterology 2002;122:A67. (Abst)

22. Enns R, Gagnon Y, Rioux K, Levy A. Cost-effectiveness in Canada of intravenous proton pump inhibitors for all patients presenting with acute upper gastrointestinal bleeding. Aliment Pharmacol Ther 2003;17:1-9.

23. Laine L, Peterson WL. Bleeding peptic ulcer. N Engl J Med 1994:331:717-27.

24. Lin HJ, Wang K, Perng CL, Lee FY, Lee CH, Lee SD. Natural history of bleeding peptic ulcers with a tightly adherent blood clot: A prospective observation. Gastrointest Endosc 1996;43:470-3.

25. Jaramillo J, Galvez C, Carmona C, Montero J, Mino G. Prediction of further hemorrhage in bleeding peptic ulcer. Am J Gastroenterol 1994;89:2135-8.

26. Kollef MH, O'Brien JD, Zuckerman GR, Shannon W. BLEED: A classification tool to predict outcomes in patients with acute upper and lower gastrointestinal hemorrhage. Crit Care Med 1997;25:1125-32.

27. Corley DA, Stefan AM, Wolf M, Cook EF, Lee TH. Early indicators of prognosis in upper gastrointestinal hemorrhage. Am J Gastroenterol 1998;93:336-40.

28. Saeed ZA, Winchester CB, Michaletz PA, Woods KL, Graham DY. A scoring system to predict rebleeding after endoscopic therapy of nonvariceal upper gastrointestinal hemorrhage, with a comparison of heat probe and ethanol injection. Am J Gastroenterol 1993;88:1842-9.

29. Katschinski B, Logan R, Davies J, Faulkner G, Pearson J, Langman M. Prognostic factors in upper gastrointestinal bleeding. Dig Dis Sci 1994;39:706-12.

30. Rockall TA, Logan RF, Devlin HB, Northfield TC. Risk assessment after acute upper gastrointestinal haemorrhage. Gut 1996;38:316-21.

31. Blatchford O, Murray WR, Blatchford M. A risk score to predict need for treatment for upper-gastrointestinal haemorrhage. Lancet 2000;356:1318-21.

32. Cameron E, Pratap J, Sims T, et al. Three-year prospective validation of a pre-endoscopic risk stratification in patients with acute upper-gastrointestinal haemorrhage. Eur J Gastroenterol Hepatol 2002;14:497-501. 
33. Coffin B, Pocard M, Panis Y, et al. Erythromycin improves the quality of EGD in patients with acute upper GI bleeding: A randomized controlled study. Gastrointest Endosc 2002;56:174-9.

34. Frossard J, Spahr L, Queneau P, et al. Erythromycin intravenous bolus infusion in acute upper gastrointestinal bleeding: A randomized, controlled, double-blind trial. Gastroenterology 2002;123:17-23.

35. Jensen D, Kovacs T, Jutabha R, et al. Randomized trial of medical or endoscopic therapy to prevent recurrent ulcer hemorrhage in patients with adherent clots. Gastroenterology 2002;123:407-13.

36. Bleau B, Gostout C, Sherman K, et al. Recurrent bleeding from peptic ulcer associated with adherent clot: A randomized study comparing endoscopic treatment with medical therapy. Gastrointest Endosc 2002;56:1-6.

37. Tekant Y, Goh P, Alexander DJ, Isaac JR, Kum CK, Ngoi SS. Combination therapy using adrenaline and heater probe to reduce rebleeding in patients with peptic ulcer haemorrhage: A prospective randomized trial. Br J Surg 1995;82:223-6.

38. Longstreth GF, Feitelberg SP. Outpatient care of selected patients with acute non-variceal upper gastrointestinal haemorrhage. Lancet 1995;345:108-11.

39. Lai KC, Hui WM, Wong BC, Ching CK, Lam SK. A retrospective and prospective study on the safety of discharging selected patients with duodenal ulcer bleeding on the same day as endoscopy. Gastrointest Endosc 1997;45:26-30.

40. Cebollero-Santamaria F, Smith J, Gioe S, et al. Selective outpatient management of upper gastrointestinal bleeding in the elderly. Am J Gastroenterol 1999;94:1242-7.

41. Longstreth GF, Feitelberg SP. Successful outpatient management of acute upper gastrointestinal hemorrhage: Use of practice guidelines in a large patient series. Gastrointest Endosc 1998;47:219-22.

42. Cooper GS, Chak A, Connors AF Jr, Harper DL, Rosenthal GE. The effectiveness of early endoscopy for upper gastrointestinal hemorrhage: A community-based analysis. Med Care 1998;36:462-74.

43. Almela P, Benages A, Peiro S, et al. Outpatient management of upper digestive hemorrhage not associated with portal hypertension: A large prospective cohort. Am J Gastroenterol 2001;96:2341-8.

44. Cooper G, Chak A, Way L, Hammar P, Harper D, Rosenthal G. Early endoscopy in upper gastrointestinal hemorrhage: Associations with recurrent bleeding, surgery, and length of hospital stay. Gastrointest Endosc 1999;49:145-52.

45. Hay JA, Maldonado L, Weingarten SR, Ellrodt AG. Prospective evaluation of a clinical guideline recommending hospital length of stay in upper gastrointestinal tract hemorrhage. JAMA 1997;278:2151-6.

46. Gisbert JP, Gonzalez L, Calvet X, Roque M, Gabriel R, Pajares JM. Proton pump inhibitors versus $\mathrm{H} 2$-antagonists: A meta-analysis of their efficacy in treating bleeding peptic ulcer. Aliment Pharmacol Ther 2001;15:917-26.

47. Zed PJ, Loewen PS, Slavik RS, Marra CA. Meta-analysis of proton pump inhibitors in treatment of bleeding peptic ulcers. Ann Pharmacother 2001;35:1528-34.

48. Messmann H, Schaller P, Andus T, et al. Effect of programmed endoscopic follow-up examinations on the rebleeding rate of gastric or duodenal peptic ulcers treated by injection therapy: A prospective, randomized controlled trial. Endoscopy 1998;30:583-9.

49. Lau JY, Sung JJ, Lam YH, et al. Endoscopic retreatment compared with surgery in patients with recurrent bleeding after initial endoscopic control of bleeding ulcers. N Engl J Med 1999;340:751-6.

50. Patel TH, Cordts PR, Abcarian P, Sawyer MA. Will transcatheter embolotherapy replace surgery in the treatment of gastrointestinal bleeding? Curr Surg 2001;58:323-7.

51. Spiegel BM, Vakil NB, Ofman JJ. Endoscopy for acute nonvariceal upper gastrointestinal tract hemorrhage: Is sooner better? A systematic review. Arch Intern Med 2001;161:1393-404.

52. Cipolletta L, Bianco M, Rotondano G, Marmo R, Piscopo R. Outpatient management for low-risk nonvariceal upper GI bleeding: A randomized controlled trial. Gastrointest Endosc 2002;55:1-5

53. Lee JG, Turnipseed S, Romano PS, et al. Endoscopy-based triage significantly reduces hospitalization rates and costs of treating upper GI bleeding: A randomized controlled trial. Gastrointest Endosc 1999;50:755-61.

54. Almela P, Benages A, Peiro S, et al. Outpatient care of upper gastrointestinal hemorrhage not related to portal hypertension. Med Clin (Barc) 2000;114(Suppl 2):68-73.

55. Lai KC, Hui WM, Wong WM, et al. Treatment of Helicobacter pylori in patients with duodenal ulcer hemorrhage - a long-term randomized, controlled study. Am J Gastroenterol 2000;95:2225-32.

56. Sharma V, Sahai A, Corder F, Howden C. Helicobacter pylori eradication is superior to ulcer healing with or without maintenance therapy to prevent further ulcer haemorrhage. Aliment Pharmacol Ther 2001;15:1939-47.

57. Riemann JF, Schilling D, Schauwecker P, et al. Cure with omeprazole plus amoxicillin versus long-term ranitidine therapy in Helicobacter pylori-associated peptic ulcer bleeding. Gastrointest Endosc 1997;46:299-304.

58. Sung JJ, Leung WK, Suen R, et al. One-week antibiotics versus maintenance acid suppression therapy for Helicobacter pyloriassociated peptic ulcer bleeding. Dig Dis Sci 1997;42:2524-8.

59. Udd M, Miettinen P, Palmu A, Julkunen R. Effect of short-term treatment with regular or high doses of omeprazole on the detection of Helicobacter pylori in bleeding peptic ulcer patients. Scand J Gastroenterol 2003;38:588-93. 


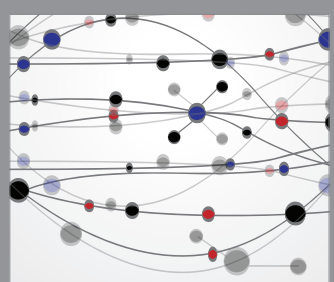

The Scientific World Journal
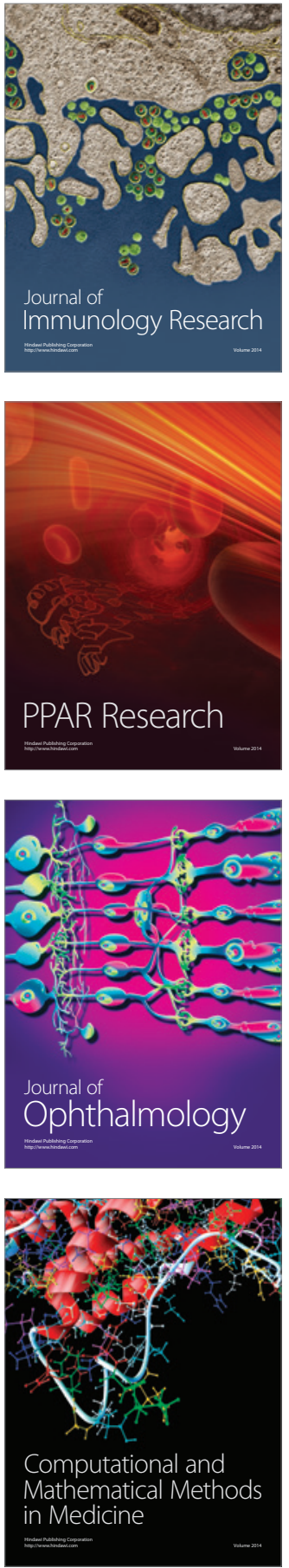

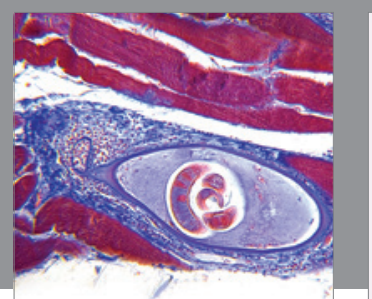

Gastroenterology Research and Practice

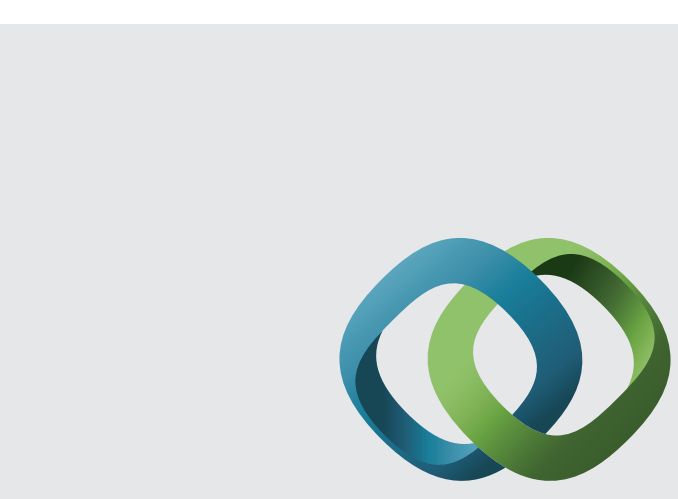

\section{Hindawi}

Submit your manuscripts at

http://www.hindawi.com
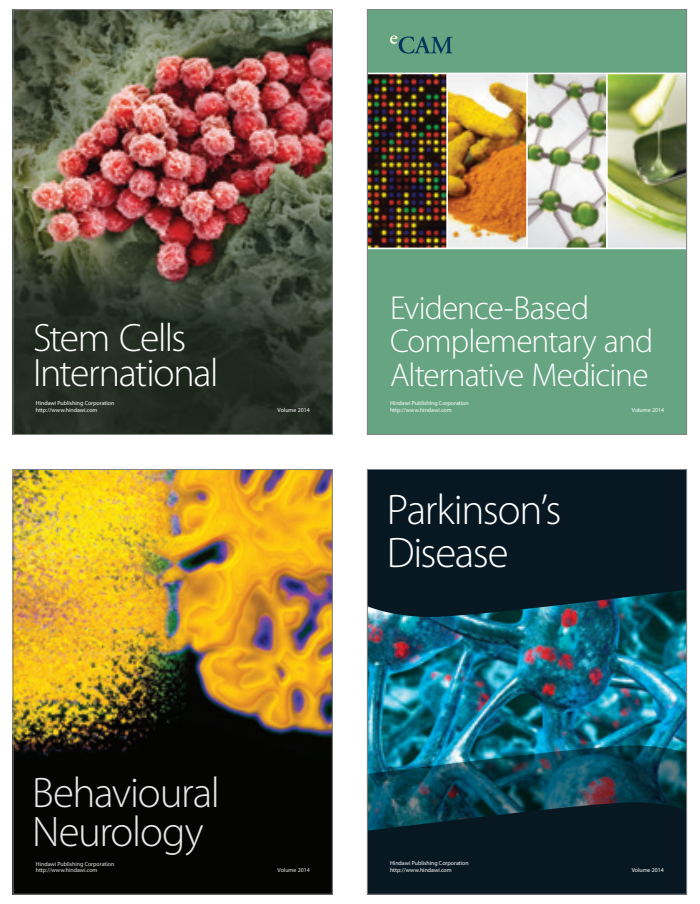
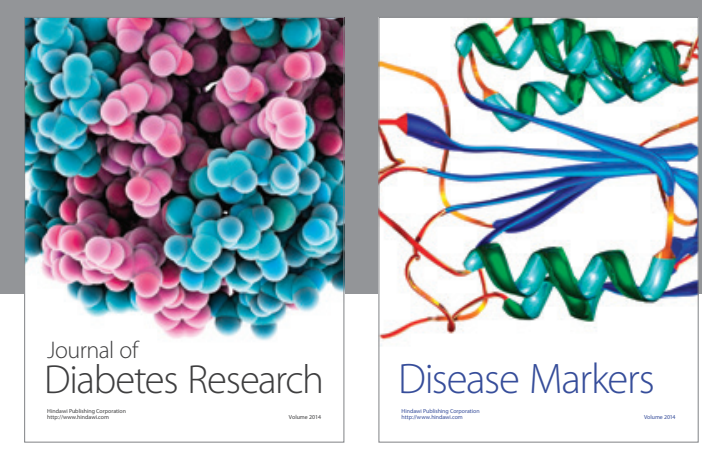

Disease Markers
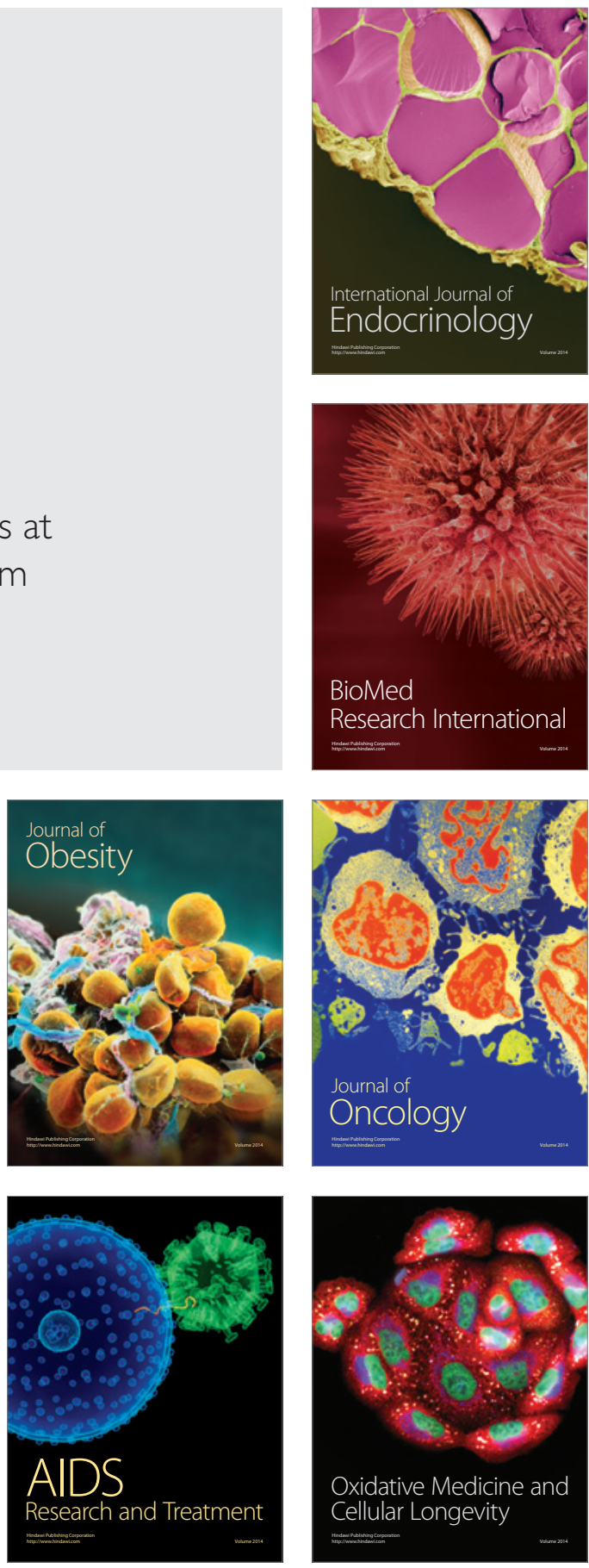